\title{
Study on the Status and International Strategy Development of Technological Enterprises
}

\author{
Lan Wang \\ School of Business, Beijing Language and Culture University, Beijing, China \\ Email:im2003@163.com
}

Received 6 November 2015; accepted 23 November 2015; published 27 November 2015

Copyright (C) 2015 by author and Scientific Research Publishing Inc.

This work is licensed under the Creative Commons Attribution International License (CC BY). http://creativecommons.org/licenses/by/4.0/

(c) (i) Open Access

\begin{abstract}
International strategy is a very hot topic today. Embedding in the global industry chain helps enterprises better integrate resources and enhance innovation capability especially for technological enterprises. Based on the data from Zhongguancun area, this thesis analyzes the current situation and problems of the internationalization of technological enterprises. And furthermore we put forward some suggestions to improve market internationalization of technological enterprises. In order to enhance the innovation capability and core competence, the government should support enterprises to explore international markets and establish a platform for technological intermediary services.
\end{abstract}

\section{Keywords}

International Strategy, Resource Integration, Technological Enterprises

\section{Introduction}

The recent worldwide generation of technology and industry revolution creates new opportunities for the international development of technological enterprises. Chinese companies should grasp the chance of new technology revolution, accelerate their innovation breakthroughs in various fields and enhance their capability of independent innovation. Meanwhile, the companies should follow the world trend of technology innovation, deepen the technology collaboration globally, get involved in the global technological innovation network actively, and substantially take the responsibilities of leading national innovations. Therefore, these companies can have head starts in the new technology revolution and industry revolution.

Currently, the international economy is still affected by the global financial crisis. In order to handle the crisis, 
developed countries are looking for new sources of economic growth, which are mostly from the integrated development of cross-countries and cross-regions, the communication of technology, capital and human resources, as well as the deepening of collaborations between industries and markets. This approach will lead the global innovation collaboration to a new phrase, and it provides chances for technological enterprises in Beijing to speed their integration in the international innovation network. Zhongguancun area is famous for technology enterprise clusters, it gathers a large number of scientific and technological enterprises. In this study, we use the data from Zhongguancun area to reveal the typical international development path of technology companies.

\section{Internationalization Stage Theory}

After the middle of 1970s, scholars from University of Uppsala in Sweden including Johanson and Wiedersheim-Paul (1975) [1], Johanson and Vahlne (1977) [2] established a new theory in their research about the internationalization of northern European companies, the enterprises' internationalization stage theory. This theory has a wider applicability since it claims that the international marketing of enterprises is a gradual modification process of the companies when they are confronting with changes of themselves and the external environment.

The internationalization of a company can be divided into four phrases: frequent exports; exports through independent agents; establishment of foreign branches; and manufacturing from foreign branches. These four phrases is a gradual procedure, indicating the deepening of internationalization. In this theory, the features are reflected in two aspects. Firstly, this theory follows a geographical progressiveness. Companies usually expand their markets in a geographical order: local market, national market, neighbor foreign market and global market. Secondly, the theory reflects transnational operation progressiveness: the domestic operation before internationalization, the indirect exports via agents when the internationalization starts, direct exports by foreign branches and foreign productions.

From the perspective of internationalization approaches, there are three approaches of enterprise internationalization: international trading, foreign economy and technological collaboration, foreign direct investment (FDI). The internationalization operational methods of enterprises can be grouped into external internationalization operational methods and internal internationalization operational methods. The research of natural international enterprises originated from the thesis "The Overview of Natural International Enterprises" by Oviatt and McDougall [3] in 1994. The thesis pointed out that the traditional internationalization theories usually focused on mature large-scale enterprises and rarely paid attention to small and medium-sized enterprises (SME). As with the development of modern communication technologies and the reduction of logistics costs, SMEs are able to obtain business chances from different countries and competitiveness. Even though current resources are limited, these SMEs can succeed in the global market [4] [5].

\section{The Current Situation and Problems of the Internationalization}

The total amount of imports and exports is an important indicator of market internationalization. The firm size and international target market are also main indicators. In recent years, the imports and exports of technological companies in Beijing increase rapidly, standing out under the circumstances of international financial crisis and fast decreases of the sum in national imports and exports. The substantial increase has contributed to the overall economic growth of the city. Confronting with the complicated international economic situation, the technological enterprises in Beijing handled the dilemma actively and solved the problems proactively. By learning advanced approaches, enhancing self-innovations, increasing the competitiveness and added-value of products and promoting the modification of industry constructions, these companies expanded their market sizes and improved the trade structures in fierce international competitions. They also got involved in the global distribution of technology and industry resources. The international influence and the right of speech of the enterprises increased gradually, promoting the development of the internationalization of companies in Beijing. We analyzed the situation and features of the technological enterprises' internationalization in the following aspects: the basic imports and exports conditions, the total amount of imports and exports, internationalized companies' sizes and internationalized target market [6] [7].

\subsection{The Basic Imports and Exports Conditions}

In recent years, the foreign trade of technological enterprises keeps growing. The internationalization level of 
technological enterprises in Beijing deepens consistently, and the international influence of them grows significantly. At the age of economic globalization, technological enterprises in Beijing adopt advanced management values, and improve their capability of self-innovation. The companies cater to the changes of consumer needs and gradually get involved in the global industry chain, enhancing their competitiveness. The growth rate of foreign trade in Beijing has decreased recently, and the adverse trade balance expands, leading to an inverse growth of foreign trade in 2014. However, under such circumstance, technological enterprises in Beijing took the advantage of innovative resources and improved the international competitiveness of high-tech products, keeping a trend of stable growth of imports and export. According to the data of technological enterprises (Table 1), from 2011 to 2014, the foreign trade of technological enterprises in Beijing kept a stable and consistent growth. In 2014, the total value of imports and exports amounted 99.58 billion dollars, consisting $24 \%$ of the total imports and exports in Beijing and drawing a new record in recent five years. The data demonstrate that the technological enterprises led the growth of foreign trade in Beijing. The continuous enhancement of Beijing industry structures has contributed to the economic growth and economic structure adjustment of Beijing positively.

\subsection{The Distribution of Imports and Exports}

The contribution to the total value of imports and exports from domestic investment and foreign investment is similar. In the total sum of imports, the rate of domestic investment is less than that of the foreign investment, although the situation is opposite in the total sum of exports. However, the differences are not significant. In domestic companies, limited liability companies have the greatest amount of imports and exports, accounting for near $50 \%$ of all domestic enterprises. According to the data from Zhongguancun, on the type of enterprises' registry, the total amount of imports and exports of domestic enterprises reached 51.581 billion dollars in 2014, accounting for $51.8 \%$ of the total value. This percentage is less than that in 2013, and the contribution of foreign trade from both domestic enterprises and foreign enterprises is similar.

Table 1. The comparison of imports and exports between technological enterprises in Beijing and the overall situation in Beijing (2010-2014).

\begin{tabular}{|c|c|c|c|c|c|c|}
\hline & Year & 2010 & 2011 & 2012 & 2013 & 2014 \\
\hline \multirow{4}{*}{$\begin{array}{l}\text { Total } \\
\text { amount of } \\
\text { imports } \\
\text { and } \\
\text { exports }\end{array}$} & $\begin{array}{l}\text { Beijing } \\
\text { (billion dollars) }\end{array}$ & 301.41 & 389.49 & 407.92 & 429.1 & 415.65 \\
\hline & $\begin{array}{c}\text { Technological enterprises (Zhongguancun) } \\
\text { (billion dollars) }\end{array}$ & 52.93 & 60.41 & 75.2 & 88.97 & 99.58 \\
\hline & Growth rate (\%) & 18.1 & 14.1 & 24.5 & 18.3 & 11.9 \\
\hline & $\begin{array}{c}\text { Technological enterprises } \\
\text { (Zhongguancun)/Beijing (\%) }\end{array}$ & 17.6 & 15.5 & 18.4 & 20.7 & 24.0 \\
\hline \multirow{4}{*}{$\begin{array}{c}\text { Total } \\
\text { amount of } \\
\text { imports }\end{array}$} & $\begin{array}{l}\text { Beijing } \\
\text { (billion dollars) }\end{array}$ & 245.94 & 330.47 & 348.27 & 365.9 & 353.31 \\
\hline & $\begin{array}{c}\text { Technological enterprises (Zhongguancun) } \\
\text { (billion dollars) }\end{array}$ & 30.1 & 36.69 & 49.03 & 55.35 & 65.85 \\
\hline & Growth rate (\%) & 25.4 & 21.9 & 33.6 & 12.9 & 19.0 \\
\hline & $\begin{array}{c}\text { Technological enterprises } \\
\text { (Zhongguancun)/Beijing (\%) }\end{array}$ & 12.2 & 11.1 & 14.1 & 15.1 & 18.6 \\
\hline \multirow{4}{*}{$\begin{array}{l}\text { Total } \\
\text { amount of } \\
\text { exports }\end{array}$} & $\begin{array}{c}\text { Beijing } \\
\text { (billion dollars) }\end{array}$ & 55.47 & 59.03 & 59.65 & 63.2 & 62.35 \\
\hline & $\begin{array}{c}\text { Technological enterprises (Zhongguancun) } \\
\text { (billion dollars) }\end{array}$ & 22.74 & 23.73 & 26.17 & 33.62 & 33.73 \\
\hline & Growth rate (\%) & 9.2 & 4.4 & 10.3 & 28.5 & 0.3 \\
\hline & $\begin{array}{c}\text { Technological enterprises } \\
\text { (Zhongguancun)/Beijing (\%) }\end{array}$ & 41 & 40.2 & 43.9 & 53.2 & 54.1 \\
\hline
\end{tabular}

Notes: Data from Zhongguancun management committee. 


\subsection{The Size of Internationalized Enterprises}

According to the size of import and export enterprises, the amount of imports and exports is positively related to the income, and the imports and exports values are totaled more than $80 \%$ for the companies that generate incomes of more than one billion. Among them, the imports are accounted more than $80 \%$ of the total imports, while the exports are accounted more than $80 \%$ of the total exports. In general, large-scale companies occupy dominating positions in international trades.

\subsection{Internationalized Target Market}

The biggest target markets for the technological enterprises in Beijing are the developed areas and countries, such as Europe, America, Japan and South Korea. Recently, the growth of technological enterprises in Beijing slowed down in the European market and kept stable in the export market in Hong Kong. Moreover, while the market shares of these technological companies increased firmly in Taiwan, Australia, India and Southeast Asia, they decreased in the American market. Currently, on the choice of location, the technological enterprises in Beijing selected their target markets in Europe, America and Southeast Asia according to their different features of products and industries. The companies emphasize on low cost to the exports to Europe and America, while focusing on technical added value when exporting to Southeast Asia and Africa and contracting foreign projects. When selecting foreign locations, these companies will choose developed countries where the technology level could be driven by the developed conditions. The chasing of capital market is more location oriented for technological enterprises, and NASDAQ is the main capital market that attracts technological companies in Beijing. According to the data from Zhongguancun, the export destinations in 2014 were majorly located in Northern Europe, America, Japan, Hong Kong, Macau and Taiwan, etc., and Northern Europe was still the top choice of exports although the growth rate slowed down. Except for Northern Europe, the export income of other regions has increased compare to that in 2013. It can be seen that the income of exports to America and Southeast Asia increased 0.11 billion dollars.

\subsection{Current Problems}

Firstly, companies are lack of core competence, and the technology innovation should be enhanced. The technology enterprises in Beijing have generated some reputable companies, but many of the enterprises are SMEs and startups. There are wide gaps between SMEs and large-scale enterprises in technology and management levels, which influence the development of the entire industry. So far, there is a lack of industry policy that motives joint development of large-scale companies and SMEs, therefore the connections between these two types of companies are not yet established. Strengthening the long-term business and technology collaboration between big companies and SMEs is an important way to enhance product quality and international competitiveness. It is the future that more technological enterprises in Beijing will be integrated into global research and development [8].

Zhongguancun demonstration plot is the most representative park for technological enterprises in Beijing. So far, 95\% of the companies are SMEs. Because their target markets and sources are within China, the pressure and intention of "going out" are low. Lacking of strong competitiveness, many companies are merely followers in the industry with insufficient critical technologies. Taking PCT international patent as an example, the PCT patent applications from Intel, HP, Google and Apple totaled 2069 in 2012, surpassing the sum in demonstration plot by 1736. Meanwhile, the mode of internationalization for technological enterprises in Beijing is single, mainly in product exports. Although there are more cases of financing mergers, acquisitions and technological collaborations in recent years, companies are not familiar with the internationalization development path and are lack of mature approaches [9] [10].

Secondly, technological enterprises are lack of core technologies. For example, foreign PC companies in information industry control core technologies of CPU, operation systems and database. Also, in the mobile phone production chain, foreign companies hold critical chips, materials, operation systems and other core technologies. Many SMEs mainly depend on domestic market and are weak at technology capabilities, so the internationalization degree of the market is rather low. The export income is accounted a little part of the total corporative income, and companies have little cutting-edge technology. According to other researches, although the technological enterprises in Beijing possess many patents, the qualities of these patents are low, and few patents 
could realize industrialization. The investment for patents in later stage and the difficulty of exploitation will be larger. Meanwhile, private-owned companies have more patents than state-owned companies. Moreover, since these companies are lack of competitiveness, they have not yet formed high-technology enterprises. According to the dominating position of foreign enterprises in Beijing, domestic companies are comparably weak. The total income, value of gross output and exports of foreign enterprises still take a significant proportion of the total value.

Thirdly, companies are dominated in the industry chain, and the industry's international competency needs to be improved. So far, the technological companies in Beijing depend mostly on exports for internationalization and less on direct investments. Also, the amount of oversea sales channels and development collaborations is small. Low strength of the companies is an important reason for low internationalization. Large transnational corporations are the main force of international investment and global resource distribution, but there is a lack of strong transnational corporations in Beijing, therefore the current companies cannot compete to foreign transnational companies in capital, technology, human resources and branding. The technological enterprises in Beijing are dominated in the industry chain, and they have not yet generated collective advantages as well as industry groups with competitive innovative core technologies. Currently, the industry groups in Beijing include electronic information, biological pharmacy, aerospace exploration, new materials, new resources and high-tech services. These groups have the biggest economic scale in China. In the global labor distribution, technological enterprises are generally dominated, and the added values are relatively low. The direction of technological enterprises' internationalization should promote the position of themselves in the global industry chain. Companies should obtain the right of speech in the global industry chain by technological innovation, business mode innovation and international brand establishment [11].

\section{Policy Suggestions in Improving Market Internationalization}

\subsection{Support Enterprises to Explore International Markets}

Firstly, by utilizing the foreign affairs resources of Beijing and China, companies could improve the efficiency of exploring international markets. Beijing should use the advantages of being a political center, use the foreign affairs resources in Beijing actively and conduct bilateral and multilateral international collaborations for a higher level of communication with international companies.

Secondly, establish collaborative policies with Chinese embassies and international organizations. By this means, Shenzhen, which previously had no foreign resources, has attracted 44 institutes from 33 countries and regions and builds up a "Shenzhen international technology business platform". Many of the institutes are the contact offices for investments and trade promotions of foreign state-owned political departments, enhancing the collaborations among Shenzhen high-tech enterprises and international companies.

Thirdly, strengthen the innovative cooperation by establishing sister cities. Many high-tech areas promote the relations with sister cities. For example, the high-tech area in Suzhou is bounded with county Kilkenny, the creative area in Ireland; the high-tech area in Changzhou holds the principles of "spread globally, develop important projects, promote consequently and lead comprehensively". Not only does Changzhou established collaborations with Hull Ford in Germany and Stavropol Industrial Zone in Russia, but it is also connected to Komatsu in Japan and Duluth in America. The companies in Beijing should make use of the international collaborations and foreign communication resources, and discuss the opportunities to connect to high-tech zones and innovation origins with reputable cities, in order to expand Beijing's potential of internationalization.

Fourthly, make use of the geographical advantage where the central government locates, and negotiate the communication and collaboration systems with related departments and Chinese embassies. Companies should receive international innovation resources and use the support and resources on research from various countries. For example, the technology department established regional or bilateral cooperation systems, bringing up major research fields and supporting the collaboration financially. Beijing should communicate with Chinese embassies closely and join important technology plans and multilateral cooperation projects actively. Beijing should attract support from multiple sources and gather international innovation resources, promoting the establishment of international technology innovation center in Beijing.

Fifthly, the government should support enterprises to join international trainings, market research and international conferences, as well as foreign exhibitions. The government should support the companies in passing authoritative international certificates, setting international branches, and obtaining services about law, consultan- 
cy and market analysis in foreign institutes. The government should offer financial policies and services to support enterprises in international competitions and collaborations. The government should found a rewarding system for enterprises' internationalization. The government can implement a method of "rewarding as compensation" to lead the companies into international developments. The government ought to reward the outstanding ones in ranking the internationalization degree among the companies, especially to those who get a certain amount of foreign income, establish foreign branches, publish abroad, and obtain international patents. The government should accelerate the decision on the rewarding system.

\subsection{Accelerate the Improvement of the Intermediary Service System on Enterprises' Internationalization}

Firstly, explore the establishment of the docking mechanism in international enterprise services. Based on the current international service platform and consistent improvements, the government should establish a docking mechanism between intermediary institutes and enterprises. The government ought to analyze the needs of internationalization and supply efficient mechanisms. It is important to solve the problem on the rewarding of intermediary services and explore the possible support from the government to lessen the cost of enterprises.

Secondly, the government should import high standard intermediary institutes. Several international intermediary institutes should set branches in Beijing and provide professional services. The government should encourage the large transnational companies to set up independent intermediary institutes internally and conduct added-value services. Meanwhile, the local intermediary institutes should be cultivated. The government should strengthen the integration of current intermediary institutes and support them to enhance their abilities. Moreover, the institutes should be encouraged to expand their business fields and provide various value-added services. The government should support incubators and the establishment of intermediaries specialized in international services.

Thirdly, build a collective area of intermediary institutes of technological internationalization. The companies should strengthen the communication with the Beijing government in order to integrate the real estate resources and establish a collective area for intermediary services. Based on the current collective zone, the intermediary institutes should expand their domain and form a service system to improve their capabilities.

\subsection{Establish a Platform for Technological Intermediary Services}

The contribution of intermediary institutes on the integration of Beijing technological industry should be highlighted. Therefore, the government should concentrate on building a comprehensive intermediary service system, including profitable organizations and non-profit organizations. The profitable intermediary organizations provide human resources, technology transformation, accounting, taxing, law, consulting, headhunting, real estate management and safety services. Besides, there are some non-profit intermediary institutes, such as some associates and unions, focusing on the promotion of innovative startups. Intermediary institutes are important participants of the technological industry system in Beijing. It is of great significance to upgrade the services under the support of the government. Currently, there are many active intermediary institutes, and more famous institutes will be imported in the future to promote the internationalization of local counterparts. It is also important to complete the system of international and local studies and researches, implement the promotion of intellectual property, set funds and import intermediary institutes and innovative information. The government should strengthen the establishment of public technology services, property information, transaction information and intermediary platform. Meanwhile, the government ought to lead and support the industry leagues and associates, emphasize the functions of industry associates and professional organizations. By promoting the transactions of properties, industrialization and internationalization of technologies and strengthening the internationalization of human resources, taxation, law and consultancy services, the intermediary institutes will provide the first-class services for the technology enterprises in Beijing.

\section{Acknowledgements}

This research is supported by BLCU (Beijing Language and Culture University) Business School supported project (supported by the Fundamental Research Funds for the Central Universities) (Approval Number: 14YJ04005), Beijing supporting Central University joint project-Young Talent Plan.( Project No. YETP0880). 


\section{References}

[1] Johanson, J. and Wiedersheim-Paul, F. (1975) The Internationalization of the Firm-Four Swedish Cases. Journal of Management Studies, 12, 305-323.

[2] Johanson, J. and Vahlne, J.-E. (1977) The Internationalization Process of the Firms: Model of Knowledge Development and Increasing Market Commitment. Journal of International Business Studies, 8, 23-32. http://dx.doi.org/10.1057/palgrave.jibs.8490676

[3] Oviatt, B.M. and McDougall, P.P. (1994) Toward a Theory of International New Ventures. Journal of International Business Studies, 25, 45-64.

[4] Porter, M.E. (2000) Location, Competition and Economic Development: Local Clusters in a Global Economy. Economic Development Quarterly, 14, 15-34. http://dx.doi.org/10.1177/089124240001400105

[5] Welch, L.S. and Luostatinen, R.K. (1993) Inward-Outward Connections in Internationalization. Journal of International Marketing, 1, 44-56.

[6] Niechels, L. (2008) Transfer Pricing in Multinational Firms: A Heuristic Programming Approach and a Case Study. John Wiley and Sons Inc., New York.

[7] Kogut, B. and Kulatilaka, N. (1994) Operating Flexibility, Global Manufacturing, and the Option Value of a Multinational Network. Management Science, 40, 123-139. http://dx.doi.org/10.1287/mnsc.40.1.123

[8] Matthyssens, P. and Vandenbempt, K. (2008) Moving from Basic Offerings to Value-Added Solutions: Strategies, Barriers and Alignment. Industrial Marketing Management, 37, 316-328.

[9] Lu, J.W. and Beamish, P.W. (2001) The Internationalization and Performance of SMEs. Strategic Management Journal, 22, 565-586. http://dx.doi.org/10.1002/smj.184

[10] Nagurney, A., Cruz, J. and Matsypura, D. (2003) Dynamics of Global Supply Chain Supernetworks. Mathematical and Computer Modeling, 37, 963-983. http://dx.doi.org/10.1016/S0895-7177(03)00112-2

[11] Huchzermeier, A. and Cohen, M.A. (1996) Valuing Operational Flexibility under Exchange Rate Risk. Operations Research, 44, 100-113. http://dx.doi.org/10.1287/opre.44.1.100 